DOI: 10.46340/eppd.2020.7.4.7

Nataliya Shelever, PhD in Law

ORCID ID: https://orcid.org/0000-0003-3641-4910

Uzhgorod National University, Ukraine

\title{
JUSTICE AS A FUNDAMENTAL PRINCIPLE OF THE CONSTITUTIONAL LAW OF UKRAINE
}

\author{
Наталія Шелевер, к. ю. н. \\ ДВНЗ «Ужгородський національний університет», Україна

\section{СПРАВЕДЛИВІСТЬ ЯК ОСНОВОПОЛОЖНИЙ ПРИНЦИП КОНСТИТУЦЙНОГО ПРАВА УКРАЇНИ}

The article is devoted to the study of the principle of justice as a key principle in constitutional law. Due to the difficulties of the modern day, namely the pandemic, the war in eastern Ukraine, corruption, the difficult economic situation, the author believes that at the moment it is appropriate to study such a value as "justice". To date, this is of great theoretical and practical importance. For the regulation of social relations, it is justice that plays an important role, because it indicates the line between what is allowed and what is not allowed. Therefore, the author tries in this article to show how this principle is embodied in law. She argues that the law should be based on the principle of justice, how much its non-observance creates injustice, which is a very dangerous phenomenon for modern society. Justice is a fundamental principle of law and the author tries to prove and justify it in her research.

Keywords: justice, principles of law, law, injustice, justice, the Constitution of Ukraine.

Справедливість аж ніяк не створено законом: навпаки, закон завжди є лише тлумаченням $i$ втіленням справедливості П’єр-Жозеф Прудон

У зв'язку з прагненням України стати повноправним членом Європейського Союзу (далі - СС) важливим питанням сьогодення $\epsilon$ удосконалення чинного законодавства України. Проте наша держава переживає важкі часи. Пандемія, війна на Сході України, складна економічна ситуація, корупція призводять до численних проблем таких як соціальна нерівність, дискримінація, бідність.

Вважаємо, що при такій ситуації виникає необхідність вивчення такої цінності як «справедливість». Це питання цікаве з огляду на те, що така базова конституційна цінність в самій Конституції України не закріплена. Лише один раз про справедливість згадується у ст. 95 Основного Закону України уякій йдеться про те, що бюджетна система України будується на засадах справедливого i неупередженого розподілу суспільного багатства між громадянами i територіальними громадами.

Як справедливо зазначає О. Головченко: «Так, статтею 129 Конституції України засаду справедливості не віднесено до основних засад судочинства. На перший план тут висувається принцип законності. Але це передбачає, що закони апріорі є справедливими і правовими. Якщо ж правомірність, або конституційність (адже саме Конституція є виразником суверенної волі народу, а отже, вона повинна бути уособленням найвищої справедливості в державі), законів та інших правових актів Верховної Ради України, актів Президента України, Кабінету Міністрів України, правових актів Верховної Ради Автономної Республіки Крим ставиться під сумнів, то відповідними органами державної влади може бути направлено звернення до Конституційного Суду України щодо вирішення питання про їх відповідність Конституції України - волі народу. Тому загалом принцип законності можна в певний спосіб співвіднести з принципом справедливості» ${ }^{1}$.

\footnotetext{
${ }^{1}$ Головченко, О. Справедливість як фундаментальний принцип права у практичній площині. Віче. $<$ http://veche.kiev.ua/journal/3334/> (2020, червень, 07).
} 
На думку С. Погребняка, «Водночас слід нагадати, що ціла низка конституційних вимог безпосередньо випливає з принципу справедливості - це свідчить також про непряме закріплення цього принципу в Конституції. Наприклад, ідея справедливості конкретизується в принципі non bis in idem, закріпленому в ст. 61 Конституції України. Принцип справедливості також обумовлює обов'язок оприлюднення нормативно-правових актів (ч. 3 ст. 57 Конституції), загальну заборону зворотної дії законів (ч. 1 ст. 58 Конституції), право не бути примушеним до свідчень проти себе (ч. 1 ст. 63 Конституції), право на судовий захист (ст. 55 Конституції) та ін.» ${ }^{1}$.

Право та справедливість взаємопов’ язані. Як влучно відмітив Ю.М. Тодика «розглядаючи право через категорію справедливості, ми отримуємо можливість побачити його вище призначення і кінцеву мету, глянути на право за межі його суворих меж» ${ }^{2}$. До речі, термін «јus» (право) походить від «iustitia» (справедливість, правосуддя).

Питання справедливості і несправедливості цікавило людство з давніх-давен. Цим питанням займалися Сократ, Аристотель, Платон, Піфагор, Геракліт, а серед сучасних українських вчених М.І. Козюбра, А.В. Петришин, П.М. Рабінович, Ю.М. Тодика, С.П. Погребняк.

Вважаємо, що дослідження нормативного змісту конституційного принципу справедливості має велике як теоретичне, так і практичне значення. Саме Конституція України задає вектор розвитку всіх інших галузей права.

Справедливість як важлива соціальна цінність є предметом вивчення філософії, політології, психології, соціології, а також права. Саме право найбільш пов'язане із справедливістю. Про це писали такі римські юристи як Павел, Папініан, Модестіан. На їхній погляд право втілює вимоги справедливості.

С. Погребняк стверджує, що «Статус справедливості, як загального конституційного принципу, не викликає жодних сумнівів. Наприклад, Конституційний Суд України неодноразово посилався на принцип справедливості. Так, на його думку, висловлену у рішенні від 2 листопада 2004 року №15-рп/2004 у справі про призначення судом більш м'якого покарання, справедливість $є$ однією з основних засад права. Конституційний Суд підкреслює, що зазвичай справедливість розглядають як властивість права, виражену, зокрема, в рівному юридичному масштабі поведінки, а справедливе застосування норм права передбачає передусім недискримінаційний підхід, неупередженість. У рішенні Конституційного Суду України від 11 жовтня 2005 року №8-рп/2005 у справі про рівень пенсії і щомісячного довічного грошового утримання підкреслюється, що діяльність правотворчих і правозастосовних органів має здійснюватися за принципом справедливості. У рішенні від 22 вересня 2005 року №5-рп/2005 у справі про постійне користування земельними ділянками Суд зазначає, що із конституційних принципів рівності і справедливості випливає вимога визначеності, ясності і недвозначності правової норми, оскільки інше не може забезпечити іiї однакове застосування, не виключає необмеженості трактування управозастосовній практиці i неминуче призводить до сваволі» («цитується за: С. Погребняком») ${ }^{3}$.

Справедливість $є$ конституційною засадою судочинства. Про це йдеться урішенні Конституційного Суду України від 30 січня 2003 року №3-рп/2003 у справі про розгляд судом окремих постанов слідчого і прокурора ${ }^{4}$ «правосуддя за своєю суттю визначається таким лише за умови, що воно відповідає вимогам справедливості і забезпечує ефективне поновлення в правах».

Є. Реньов зазначає: «Закріплюючи інструментальний набір способів вирішення соціальних протиріч, Конституція України одночасно виступає і аксіологічною основою зняття соціальних протиріч, що в практико-прикладній діяльності органів публічної влади відображаються шляхом дії випливаючих з Основного Закону критеріїв конституційності прийнятих ними рішень. Особливе місце в системі конституційних критеріїв вирішення соціальних протиріч належить вимогам справедливості.

У вимоги справедливості, за змістом Конституції України, багатоплановий, універсальний зміст, який має різні нормативно-правові форми свого прояву. Він виступає і як інститут правового статусу людини і громадянина, і як принцип правової держави, i, більш того, як деяка політико-

\footnotetext{
${ }^{1}$ Погребняк, С. (2009). Закріплення основоположних принципів права в Конституції України. Вісник Академії правових наук Украӥни, 4(59), 31, 32.

2 Тодыка, Ю. (2004). Основы конституционного строя Украины. Харьков: Факт, 2.

${ }^{3}$ Погребняк, С. (2009). Закріплення основоположних принципів права в Конституції України. Вісник Академії правових наук України, 4(59), 32.

${ }^{4}$ Офіиійний вісник Украӥни. 2003, 6, ст. 245.
} 
правова основа громадянського суспільства, особлива форма досягнення юридичної рівноваги на основі балансу інтересів різних соціальних груп» ${ }^{1}$.

Конституційний принцип справедливості є надзвичайно важливим. 3 однією сторони, він вимагає однакового застосування закону до осіб, які знаходяться в подібних ситуаціях. 3 іншої сторони, диференційованого застосування до суб'єктів, які знаходяться в різних ситуаціях. Окрім цього невизначена по своєму змісту норма не забезпечує рівного масштабу іiі застосування до суб'єктів права. Таким чином порушується принцип справедливості. Вимога формальної визначеності права вимагає, що закон повинен бути зрозумілим, точним і не мати двох значень. В іншому випадку це означало б можливість неоднозначного розуміння і тлумачення закону, довільного його застосування. Принцип справедливості протистоїть юридичному свавіллю, яке на жаль, панує в нашій державі. Тому вважаємо, що першочерговим завданням для України, яка прагне стати повноправним членом Свропейського Союзу, $\epsilon$ зміцнення принципу справедливості як основоположного принципу права.

У сфері реалізації права справедливість проявляється, зокрема, у рівності всіх перед законом, відповідності злочину і покарання, цілях законодавця і засобах, що обираються для їх досягнення.

О. Головченко стверджує, що «Окремим виявом справедливості є питання відповідності покарання вчиненому злочину; категорія справедливості передбачає, що покарання за злочин має бути домірним злочину. Справедливе застосування норм права $є$ передусім недискримінаційним підходом, неупередженістю. Це означає не тільки те, що передбачений законом склад злочину та рамки покарання відповідатимуть одне одному, а й те, що покарання має бути в справедливому співвідношенні із тяжкістю й обставинами скоєного та особою винного. Адекватність покарання ступеню тяжкості злочину випливає з принципу правової держави, із суті конституційних прав та свобод людини і громадянина, зокрема права на свободу, які не можуть бути обмежені, крім випадків, передбачених Конституцією України»².

Отже, принцип справедливості є основоположним принципом в праві, який пов'язаний із такими категоріями як «законність», «верховенство права», «рівність усіх перед законом».

В судочинстві принцип справедливості займає також важливу роль, адже саме ним потрібно керуватися судді при вирішенні справи. Принцип справедливості є важливим у випадку прогалин у законодавстві. Так, у відповідності до п.6 ст.7 Кодексу адміністративного судочинства України « у разі відсутності закону, що регулює відповідні правовідносини, суд застосовує закон, що регулює подібні правовідносини (аналогія закону), а за відсутності такого закону суд виходить iз конституційних принципів і загальних засад права (аналогія права)»³.

У пункті 2 статті 8 Цивільного кодексу України зазначено, що «у разі неможливості використати аналогію закону для регулювання цивільних відносин вони регулюються відповідно до загальних засад цивільного законодавства (аналогія права)». У відповідності до підпункту 6 пункту 1 статті 3 Цивільного кодексу України до загальних засад цивільного законодавства відносять справедливість, добросовісність та розумність ${ }^{4}$.

Конституційний принцип справедливості вимагає однакового застосування закону до осіб, які знаходяться в подібних ситуаціях. Диференційований підхід має застосовуватися до суб’єктів, які знаходяться в різних ситуаціях.

Кожна норма права має мати чіткий зміст і має однаково застосовуватися до всіх суб'єктів права, не порушувати принцип справедливості. Закон повинен бути точним, чітким і недвозначним. У такому випадку не буде неоднозначного розуміння i тлумачення закону, довільного його застосування. Принцип справедливості має протистояти юридичній сваволі.

Т. Подковенко робить такі цікаві висновки: «Справедливість - це одна з найважливіших проблем сучасності, яка відображає доволі складні, неоднозначні діалектичні процеси суспільного розвитку. Разом з уявленнями людей про свободу і рівність, щастя і гармонію, справедливість входить у цілісну систему загальнолюдських ідеалів та цінностей. Справедливість є внутрішнім змістом

\footnotetext{
${ }^{1}$ Ренёв, Е. (2016). Справедливость как базовая конституционная ценность. Legea și viața, 6/2, 93.

${ }^{2}$ Головченко, О. Справедливість як фундаментальний принцип права у практичній площині. Biче. $<$ http://veche.kiev.ua/journal/3334/> (2020, червень, 07).

${ }^{3}$ Кодекс адміністративного судочинства України, cm.7, гл. 1. 2005 (Верховна Рада України). Офіційний сайт Верховної Ради України. < https://zakon.rada.gov.ua/laws/show/2747-15> (2020, червень, 07).

${ }^{4}$ Цивільний кодекс, ст. 3, гл. 1. 2003 (Верховна Рада України). Офіційний сайт Верховної Ради Украӥни.

$<$ https://zakon.rada.gov.ua/laws/show/435-15> (2020, червень, 10).
} 
права, його внутрішнім наповненням, вона володіє безмежним гуманістичним потенціалом. Саме завдяки такому внутрішньому наповненню право еволюціонує, розвивається, збагачується саме та наповнює якісним змістом існуючі суспільні відносини. Однак такі процеси не відбуваються автоматично та самі по собі. Для утвердження справедливості, для відстоювання істинного права потрібна сильна особистість, сильна в аспекті здатності протистояти неправді, злу, несправедливості - особистість, яка здатна щоденно збагачувати право, наповнювати його зміст правдою, гуманізмом і справедливістю. Тими незаперечними істинами, які і складають безумовний смисл права як суспільного явища. Завжди потрібно пам'ятати, що право повинно бути справедливим. Це одночасно і вимоги моралі, це і вимоги природного права, це одночасно і сучасні вимоги існування людства. Справедливість $є$ основою права та одним із базових, основоположних правових принципів. Існування права без справедливості є доволі сумнівним. Оскільки закон, в якому нівелюється принцип справедливості стає неправовим, деспотичним, свавільним приписом влади, він вивищує владу над людиною, робить людину засобом для досягнення вузьких державницьких цілей» ${ }^{1}$

На думку В.О. Васильчука, «У конституційно-правових відносинах справедливість $є$ критерієм легітимації державної влади та умовою ії суверенності. Принцип справедливості реалізується шляхом забезпечення рівної та відкритої процедури доступу до державних посад. Відображення принципу «кожному своє» у діяльності держаних органів є розподіл компетенції між різними гілками влади, а також визначення меж повноважень та сфери діяльності кожної з них. Дотримання уповноваженими суб'єктами у своїй професійній діяльності вимоги домірності, заборони перевищення необхідної міри, вимоги однакового поводження та заборони зловживання правом забезпечує здійснення державної влади на засадах справедливості»².

О. Головченко зазначає: «На жаль, поки що не існує чіткого визначення «справедливості», яке було б загальнообов'язковим та універсальним для всіх. Найвдалішим у цьому сенсі $є$ розуміння «справедливості» як уявлення про належне, що містить вимогу про відповідність діяння та відплати за нього. Таке визначення здається квінтесенцією, найвищою абстракцією усіх спроб пояснити поняття «справедливість» i, безперечно, претендує на роль найширшого і найзагальнішого. Однак воно не розв'язує багатьох проблем, які постають на шляху досягнення консенсусу саме щодо уявлень про ту міру належного, що врівноважує заслуги людини з їх визнанням, працю з винагородою за неї, злочин - $з$ покаранням тощо.

Справедливість за своєю суттю $є$ поняттям релятивним, що віддзеркалює соціальні реалії того чи іншого суспільства, рівень його культурної, правової зрілості. Сьогодні справедливість відіграє роль своєрідного індикатора, який дає конкретне уявлення про відповідність моделі соціальної та правової держави іiі фактичному стану в суспільстві. Справедливість проявляється на різних суспільних щаблях та в різних просторових i часових вимірах. Так, існує індивідуальна справедливість, яка виражається у ставленні конкретного індивіду до навколишнього світу, існує справедливість між поколіннями, що не обмежена часовими рамками, існує справедливість між народами, націями, державами, яка виходить за межі конкретної території. Можна спробувати розподілити справедливість на види, висловлювати різні про неї міркування, дискутувати, доводити або спростовувати факт іiі існування. Але не можна заперечувати важливість значення справедливості для людини і людства, особливо у правовій сфері» ${ }^{3}$.

M.А. Бурдоносова вважає, що «Справедливість як правовий принцип виявляється у відповідності між законодавчо закріпленими взаємозалежними правами, свободами, обов'язками, відповідальності за вчинені правопорушення. Вона має особливе значення для регулювання суспільних відносин, оскільки найбільш суттєві соціальні наслідки викликає саме несправедливість, закріплена в законодавстві. Таким чином, право як основоположний соціальний регулятор має своїм підгрунтям ідеї справедливості, рівності, свободи і гуманізму» ${ }^{4}$.

На нашу думку, принцип справедливості $є$ ключовим принципом у праві. Конституція України визначає вектор розвитку всіх інших галузей вітчизняного права. Тому дослідження конституційного

\footnotetext{
${ }^{1}$ Подковенко, Т. (2016). Справедливість у системі цінностей права. Актуальні проблеми правознавства, 4 (8), 13.

${ }^{2}$ Васильчук, В.О. Справедливість як категорія права.

$<$ http://dspace.lvduvs.edu.ua/bitstream/1234567890/181/1/vasylchuk.pdf> (2020, червень, 10).

${ }^{3}$ Головченко, О. Справедливість як фундаментальний принцип права у практичній площині. Biче.

$<$ http://veche.kiev.ua/journal/3334/> (2020,червень, 07).

${ }^{4}$ Бурдоносова, М. А. (2019). Генеза справедливості як основоположного принципу права. Актуальні проблеми вітчизняної юриспрудениії, 2,6.
} 
принципу справедливості є актуальним питанням сьогодення та вимагає подальшого вивчення як теоретиками, так і практиками. Конституція України закріпила віру у справедливість та захищає права громадян. Проте важливим питанням є саме реалізація гарантованих Основним Законом України прав громадян. Адже часто в нашій державі ми спостерігаємо ситуацію, коли справедливість є лише на папері, а в реальному житті вона відсутня. Тому необхідним є дослідження нормативного змісту принципу справедливості та регулятивного його потенціалу.

\section{References:}

1. Holovchenko, O. Spravedlyvist yak fundamentalnyi pryntsyp prava u praktychnii ploshchyni [Justice as a fundamental principle of law in the practical plane]. Viche [Viche]. $<$ http://veche.kiev.ua/journal/3334/> (2020, June, 07). [in Ukrainian].

2. Pohrebniak, S. (2009). Zakriplennia osnovopolozhnykh pryntsypiv prava v Konstytutsii Ukrainy [Consolidation of fundamental principles of law in the Constitution of Ukraine]. Visnyk Akademii pravovykh nauk Ukrainy [Bulletin of the Academy of Law Sciences of Ukraine], no. 4(59), 31-39. [in Ukrainian].

3. Todyka, Ju.N. (2004). Osnovy konstitucionnogo stroja Ukrainy [Fundamentals of the constitutional system of Ukraine]. Kharkiv: Fakt. [in Russian].

4. Ofitsiinyi visnyk Ukrainy [The Official Bulletin of Ukraine], 2003, no. 6, st.245. [in Ukrainian].

5. Renev, E. (2016). Spravedlivost' kak bazovaja konstitucionnaja cennost' [Justice as a basic constitutional value]. Zakon i Zhizn' [Law and Life], no. 6/2, 93. [in Russian].

6. Kodeks administratyvnoho sudochynstva Ukrainy 2005 [Code of Administrative Procedure of Ukraine 2005] (Verkhovna Rada Ukrayiny) [(Verkhovna Rada of Ukraine)]. Ofitsiynyy sayt Verkhovnoyi Rady Ukrayiny [The official website of the Verkhovna Rada of Ukraine]. <https://zakon.rada.gov.ua/laws/show/2747-15> (2020, June, 07) [in Ukrainian].

7. Tsyvil'nyy kodeks 2003 [Civil Code 2003] (Verkhovna Rada Ukrayiny) [(Verkhovna Rada of Ukraine)]. Ofitsiynyy sayt Verkhovnoyi Rady Ukrayiny [The official website of the Verkhovna Rada of Ukraine]. $<$ https://zakon.rada.gov.ua/laws/show/435-15> (2020, June, 10) [in Ukrainian].

8. Podkovenko, T. (2016). Spravedlyvist u systemi tsinnostei prava [Justice in the system of values of law]. Aktualni problemy pravoznavstva [Actual problems of law], no. 4 (8), 13. [in Ukrainian].

9. Vasylchuk,V.O. Spravedlyvist yak katehoriia prava [Justice as a category of law]. $<$ http://www.philosophylawdep.chnu.edu.ua/professors/files/publications/victoria_vasylchuk/autoreferat.pdf $>$ (2020, June, 10). [in Ukrainian].

10. Burdonosova, M.A. (2019). Heneza spravedlyvosti yak osnovopolozhnoho pryntsypu prava [The Genesis of Justice as a Fundamental Principle of Law]. Aktualni problemy vitchyznianoi yurysprudentsii [Actual problems of domestic jurisprudence], no. 2, 6. [in Ukrainian]. 